\title{
Portfolio Diversification Benefits in Southeast Asian Stock Markets for Turkish Investors
}

\author{
Souhaila Guedira ${ }^{a}$ \\ Istanbul Sabahattin Zaim University Turkey \\ Mohamed Ariff \\ INCEIF Malaysia
}

\begin{abstract}
This study is a pioneering attempt at investigating portfolio diversification benefits available to the Turkish conventional and Shari'ah-compliant investors in the Southeast Asian conventional and Islamic stock markets at different investment horizons. We use multivariate-generalized autoregressive conditional heteroscedastic (MGARCH-DCC) and wavelet approaches. The results suggest that the Malaysian stock market offers substantial diversification benefits for the Turkish conventional and Islamic investors, especially for the short-run investment horizons up to 16 days, as well as for long-term investment periods exceeding 128 days. In addition, Turkish conventional investors could also consider investing in Thailand Islamic equities in short-run holding periods up to 16 days. As for the medium investment horizons from 16 to 128 days, it is advisable for the Turkish investors to avoid investing in all the equities because of very low diversification benefits.
\end{abstract}

Keywords: International portfolio diversification, Islamic stock market investments, MGARCH-DCC, Southeast Asia, Turkey, wavelets

JEL classification: G11, G15, F21, F32

\section{Introduction}

With the globalisation and liberalisation of the financial markets, investors across the world are on the lookout for investing beyond the boundaries of their countries in order to increase their returns and to take benefits from international diversification. The market portfolio theory was discussed first by Markowitz (1952), followed by several researches such as Fama and French (1995), Lintner (1965), Sharpe (1964), Ross (1976) and others. In addition, a study by Grubel (1968) has revealed that international portfolio diversification reduces the associated risk. From investors' perspective, it is

a Department of Islamic Economics and Finance, Graduate Education Institute, Istanbul Sabahattin Zaim University (IZU), Halkalı Cad. No: 281 Halkalı, Küçükçekmece, 34303 Istanbul, Turkey. Email: souhaila. guedira@kedgebs.com

b School of Graduate and Professional Studies, International Centre for Education in Islamic Finance (INCEIF), Lorong Universiti A, 59100 Kuala Lumpur, Malaysia. Email: ariff@inceif.org (Corresponding author)

* This paper is a revised version of the Master's thesis dissertation of the first author under the supervision of the second author for the Master of Science (MSc) in Islamic Finance, INCEIF, Malaysia.

Article Info: Received 26 November 2019; Revised 15 September 2020; Accepted 29 September 2020 https://doi.org/10.22452/MJES.vol57no2.6 
highly important to identify a mix of international stock markets in order to create the best and optimal portfolio combination leading to lower risks and higher returns (Dajcman, Festic, \& Kavkler, 2012). In fact, international diversification depends basically on the level of correlations and interdependence across the concerned markets (Engle, 2002; Grubel \& Fadner, 1971): a higher correlation or co-movement between two asset returns of international stock markets implies lower advantages and benefits of portfolio diversification between them (Xiao \& Dhesi, 2010). Lower risks in international diversification is strongly linked to low correlations across cross-border markets (Grubel \& Fadner, 1971). Another element which is important for investors and fund managers is the different investment horizons. In other words, the market returns are not only time varying, but may also depend on time scales associated with different stock holding periods (Gençay, Selçuk, \& Whitcher, 2001a; 2001b).

The global financial markets have witnessed over the past decade a rapid expansion of the Islamic financial sector. The Islamic financial system relies on the fundamentals of Islamic Law or Shariah which demands that earnings and benefits from investments should be gained in an ethical and socially responsible way in compliance with Islamic values (DeLorenzo, 2000). According to the International Islamic Financial Market (IIFM, 2010), the Islamic financial sector is growing at an annual growth rate of $15 \%$ to $20 \%$ per annum over the past decade. Accordingly, Thomson Reuters (2016) reported that the size of Islamic equity market globally was estimated at USD60 billion in 2015 and expected to be USD77 billion by the end of 2019. These facts are attracting investors from cross-border countries to invest in Islamic equity markets expecting portfolio diversification benefits and risk hedging. In their study, Saiti, Bacha and Masih (2014) found that the Islamic countries provide better diversification opportunities compared to the Far East countries along with important policy implications for the local and international investors regarding their portfolio diversification for hedging purposes against risks. In the most populous Muslim country Indonesia, the equity market has been experiencing rapid growth during past decades, especially in Islamic equity indices, achieving a significant growth in Shari'ah-compliant funds (Thomson Reuters, 2016). The Indonesian Islamic equity markets was estimated at USD2,157 million in 2014 , where $42 \%$ of the Shari'ah-compliant funds were issued by local institutions. Consequently, Indonesia is expected to be among leaders of the Islamic finance industry in the future. Furthermore, Malaysia is one of the fast-growing and open economies in the region, and the Malaysian stock market is one of the largest in Southeast Asia. Malaysia launched two Shariah Indices, FTSE Bursa Malaysia EMAS Shariah Index and FTSE Bursa Malaysia Hijrah Shariah Index designed for Shariah-compliant investment products, meeting the requirements of international Islamic investors.

Several studies have explored the benefits of portfolio diversification among emerging markets. Markellos and Siriopoulos (1997) found that diversified portfolios across the European emerging stock markets would lead to significant potential benefits. Worthington, Katsuura and Higgs (2003) examined stock price linkages among three developed markets (Japan, Hong Kong and Singapore) and six Asian emerging markets (Malaysia, Indonesia, Korea, Thailand, Philippines and Taiwan) in the period of the Asian financial crisis. Dunis and Shannon (2005) who explored the equity markets of Indonesia, Malaysia, Philippines, China, Korea, Taiwan and India found that international 
diversification offers benefits for the US investors. According to a study by Abdullah, Saiti and Masih (2016), Singapore is expected to influence other countries in the Southeast Asian region, given its developed nation status with an advanced capital market.

Turkey is considered the 18th largest economy in the world, with rapid growth during the last decade where per capita income has almost tripled to exceed USD10,000 currently. Moreover, Turkey is nowadays a home for Islamic finance activities, Shariahcompliant or "participative" banks, with growing potentials for investments. Dagli, Sivri and Bank (2011) showed in their study that Turkish investors could take advantage from diversification opportunities in the stock markets of Indonesia, Malaysia, Philippines, China and South Africa instead of other emerging markets. This approach aims to investigate investment opportunities and benefits for Turkey in other regions and countries rather than its traditional trading partners in Europe and MENA regions.

The main motivation of this study is to examine and explore the existence of opportunities for Turkish portfolio investors in four Southeast Asian countries, namely Malaysia, Indonesia, Singapore and Thailand. The purpose of our research is to investigate this issue for conventional and Islamic (or Shariah-compliant) stock markets, using multivariate generalized autoregressive conditional heteroscedastic dynamic conditional correlations (MGARCH-DCC) model of Engle (2002). We also attempt to verify and examine the issue for different time scales and investment horizons using wavelet approaches. For that we use the continuous wavelet transform (CWT) to check the portfolio diversi-fication benefits through correlation linkages between the different stock markets across different investment holding periods and time-frequency space. Then we apply the maximal overlapping discrete wavelet transform (MODWT) wavelet technique as a robustness test as it provides exact correlation coefficients for each scale.

The contribution of this study to the existing literature relates to investigation of diversification opportunities between Turkey and Southeast Asian conventional and Islamic markets. To the best of our knowledge, our study is the first to assess such relationships. Previous researches studied the portfolio diversification possibilities for a given country (e.g. Indonesia, Malaysia, Saudi Arabia, etc.) vis-à-vis its major trading partners only, with the focus on conventional or Islamic stock markets (Ali \& Masih, 2016; Dwihasri \& Masih, 2015; Sakti, Masih, Saiti, \& Tareq, 2018; Umirah \& Masih, 2017). Several studies have looked into diversification opportunities in Turkey's regional trading partners such as MENA region countries (Buriev, Dewandaru, Zainal, \& Masih, 2018; Mansourfar, Mohamad, \& Hassan, 2010) and Europe (Hourvouliades, 2009; Onay, 2006). Dagli, Sivri and Bank (2011) explored the portfolio diversification benefits for Turkey in emerging countries including Indonesia and Malaysia, but the period covered is not recent (1994-2010). In our study, the period covered runs from June 2007 to October 2018.

The stated objectives of this paper are as follows: (i) to find out if there are any portfolio diversification benefits for Turkey and Turkish investors (conventional) to invest in the Southeast Asian markets to gain international portfolio diversification benefits; (ii) to examine if Shariah and Islamic investors from Turkey have any portfolio diversification benefits from the Southeast Asian Islamic stock markets; and (iii) to ascertain whether the answers to the above queries would vary if we consider different holding periods 
(such as 2-4 days, 4-8 days, 8-16 days, etc.) for the conventional and Islamic investors, as there are a variety of investors holding different expectations from the financial markets.

The rest of this paper is structured as follows. Section 2 discusses the theoretical framework based on a survey of literature related to international portfolio diversification, Islamic stocks performance, and portfolio diversification opportunities in the Southeast Asian region. Section 3 elaborates the data set and methodology employed - including MGARCH-DCC model of Engle (2002), CWT and MODWT analysis. Section 4 contains a comprehensive data analysis, empirical findings and discussion of various multivariate time series techniques along with economic analysis. Finally, Section 5 concludes the paper with policy implications.

\section{Literature Review}

The main underlying theory for the present paper is the "modern portfolio theory" of Markowitz (1959) which states that: "when we hold diversified portfolios, the contribution to portfolio risk of a particular security will depend on the covariance of that security's return with those of other securities, and not the security's variance" (Bodie, Kane, \& Marcus, 2008). Markowitz explains that each security holds its own risk, and a portfolio of diverse security could represent a lower risk than a single security portfolio. In other words, a portfolio diversification with reduced or negative correlation between the securities would represent less risk weight (volatility) compared to the average risk weights of the standard deviation of the individual securities. This would lead to optimum portfolio diversifications and reduced risk.

Studies related to the domestic investors' benefits arising from international stock market diversification began in the 1970s, with the growing interest of academics and practitioners in foreign equities and diversification opportunities for investors. Noteworthy contributions include Black and Litterman (1992), Grubel (1968), Jankus (1998), Jorion (1989), Levy and Sarnat (1970), Solnik (1974) and Solnik and Noetzlin (1982). The aim of these studies was to investigate the constant correlations of the creation of international portfolios to earn diversification benefits, and to assess the different risks associated and their size. According to Aiello and Chieffe (1999), international diversification can reduce investment risk to about $56 \%$ compared with national diversification. A study by Coeurdacier and Guibaud (2011) found that investors prefer to hold foreign equity in countries that offer better diversification opportunities (countries whose stock markets are less correlated with their own) in order to gain hedging benefits against their domestic risk.

However, some studies have produced evidence against international diversification. Solnik and Noetzlin (1982) argued that the currency risk (exchange rate risk) may be higher than the return on a foreign investment or its hedging effect against the domestic risk. Jorion and Roisenberg (1993) supported this point of view insisting that transaction costs in international equity portfolios are significantly important and higher than the expected returns. In other words, international investments face currency fluctuations, administrative barriers and higher costs. Concerning emerging markets of Southeast and Northeast Asia, Dunis and Shannon (2005) affirmed in their study that these markets have become more closely integrated, which means that the 
benefits of international diversification might be diminishing. In addition, the "domino effect" of the East Asian financial crisis in 1997-1998 is a good illustration to the high vulnerability of emerging markets to individual event risk, being more sensitive to political events and considerations than economic ones, which is another argument against international diversification in emerging markets.

\subsection{Islamic Stocks and Portfolio Diversification}

It is crucial for Islamic investors and fund managers to consider the Islamic stock market in their studies in order to get a clearer idea about the risk levels and potential international portfolio diversification opportunities (Abdullah et al., 2016). In fact, Islamic (or Shariah-compliant) investment funds registered an average annual growing rate of 28\% during the period from 1994 to 2006, increasing from USD800 million to USD16 billion, encompassing 126 Islamic managed funds in 2006. Moreover, there are currently around 100 Islamic equity funds managed globally, with investments totalling more than USD5 billion in an Islamic financial market of about USD230 billion and growing at a rate of $12 \%$ and $15 \%$ per year (Sadeghi, 2008).

Empirical studies on Islamic stock market integration are relatively limited compared to studies on conventional stock markets in the West and Islamic countries (Moeljadi, 2012). Hakim and Rashidian (2004) explored the returns performance of the Dow Jones World Index (DJW), Dow Jones Sustainability World Index (DJS) and Dow Jones Islamic Market Index (DJIM) using CAPM model and found that the DJIM performed relatively better than the DJW, but not as well as DJS. In another study, Hussein (2007) affirmed that Islamic indexes offer positive abnormal returns to investors during the whole bull period; however, when it comes to the bear market, they lag behind their non-Islamic index counterparts. Achsani, Effendi and Abidin (2007) found that there are strong correlations between the Islamic stock indices of the US and Canada, Japan and Asia Pacific, Indonesia and Malaysia, in an asymmetric way across the same geographical area, which is not true across region, while the Islamic stock market in the US has a strong effect on other Islamic stock markets.

Aziz and Kurniawan (2007) confirmed in their study that the Islamic stock markets of Indonesia (the Jakarta Islamic Index) and Malaysia (the Kuala Lumpur Shari'ah Index) have significant leverage and asymmetric effects that should be considered by investors seeking potential and important diversification benefits. Majid and Kasim (2010) showed that portfolio diversification benefits in Islamic stock markets could be achieved across economic groupings such as developed, developing and emerging countries. Furthermore, Islamic markets offer better portfolio diversification opportunities than the Far East countries, with higher benefits for hedging against unforeseen risks (Saiti et al., 2014).

However, Abderrezak (2008), taking into account Islamic equity funds (IEFs) during the period of January 1997 till August 2002, found that Islamic fund's performance was poor compared to their conventional indices, and that IEFs suffer from insufficient diversification. According to Hoepner (2010), the performance of Shari'ah-compliant funds was inferior to the conventional ones in some cases, depending on the investment style. In the case of developed countries in the West, Dewandaru, Rizvi, Masih, Masih and 
Alhabshi (2014) affirmed that Islamic portfolios experience higher exposure to external shocks compared to domestic stocks. Ajmi, Hammoudeh, Nguyen and Sarafrazi (2014) found evidence of a strong linear relationship between Islamic and conventional equity markets, and this link is even stronger in countries with a well-developed Islamic finance. El Alaoui, Dewandaru, Rosly and Masih (2015) reinforced this evidence through their findings that there are heterogeneous correlations between Islamic and conventional stock markets, meaning that Islamic equities provide less diversification opportunities for traditional investors. Najeeb, Bacha and Masih (2015) suggested that Islamic stock markets offer diversification opportunities which are restricted to short-term investment, meaning that long-term investments will drive less portfolio diversification benefits.

Other studies showed mixed findings where Islamic funds do better than conventional funds in some cases, but there exist cases where the opposite is true (Elfakhani, Hassan, \& Sidani, 2005; Leong \& Aw, 1997; Mohamad \& Nassir, 1995).

\subsection{Portfolio Diversification in Southeast Asia}

Masih and Masih $(1997,1999)$ affirmed the existence of cointegration relationships among the stock markets of Malaysia, Singapore, Thailand, the US, the UK, Hong Kong and Japan during the anterior period of the financial crisis of 1987. However, they have not found any long-run relationship between these markets in the post-crisis period. Ng (2002) found that there was no evidence of cointegration relationship across the ASEAN stock markets (Indonesia, Malaysia, Thailand, Philippines and Singapore) during the period 1988-1997. However, the ASEAN stock markets have become more closely linked from 1993 to 1997. More specifically, the Indonesian, Thai and Filipino stock markets have shown a closer linkage trend with the Singaporean stock market, which is not the case for the Malaysian stock market which has become less closely linked to it over the same period. Click and Plummer (2005) showed that the stock markets of Indonesia, Malaysia, Philippines, Singapore and Thailand in the post-crisis period (1998-2002) were cointegrated, meaning that the integration was not complete.

These findings imply that there are reduced long-run diversification benefits (in comparison with short-run ones) for international investors in the Southeast Asian stock markets. De Gooijer and Sivarajasingham (2008), who investigated the long-term causal linkages among six industrialized markets and five emerging markets of Southeast Asia for the period of 1987-2006, found that the Southeast Asian stock markets have become more internationally integrated after the Asian financial crisis, which meant that, for international investors, portfolio diversification benefits offered by Southeast Asian countries are limited.

In the case of Islamic stock markets, the findings of Aziz and Kurniawan (2007) affirm that the Islamic stock markets of Indonesia (the Jakarta Islamic Index) and Malaysia (the Kuala Lumpur Shariah Index) have significant leverage and asymmetric effects that should be considered by investors seeking potential and important diversification benefits. Saiti et al. (2014) showed that Islamic equity investments provide diversification opportunities for the US-based investors in regions such as Japan, Gulf Cooperation Council (GCC) countries, Indonesia, Malaysia, and Taiwan. Regarding the efficiency of Islamic stock markets, Rizvi, Dewandaru, Bacha and Masih (2014) have explained that 
in the short term, developed stock markets show higher and better performances. Among the Islamic markets, Malaysia, Indonesia and Turkey have performed better than others. These findings reflect that the efficiency of stock markets is linked to the stage of stock market development in a concerned country. A study by Abdullah et al. (2016) investigated the relation between crude oil price and Islamic stock indices in the Southeast Asian countries including Indonesia, Malaysia, Philippines and Singapore. Their results show that the Philippine Islamic stock index is less correlated with the crude oil in the short term, offering diversification benefits in the short run, and that investors holding crude oil could gain by including the Malaysian Islamic stock index in their portfolios. Moreover, the findings indicate that Singapore is expected to affect other countries in the region since it is a developed nation with an advanced capital market. However, for the Islamic Stock Index Return (ISIR), Indonesia is expected to take the lead of other ISIR in the region as Indonesia represents the largest economy in Southeast Asian region with the most population.

The literature thus far is not conclusive. Our study is a humble attempt to add to the literature and answer some important questions regarding the Southeast Asian stock markets which an international investor would like to have. By using daily data, the findings would provide investors with insights on taking decisions in making better asset allocation of their portfolios. This paper is based on a theory linked to portfolio diversification, which is the "efficient market theory". It is argued that it is impossible to "beat the market", assuming that, in an efficient stock market, the prices reflect all available and relevant information. Thus, stocks are always traded at their fair value, which means that an investor can trust the market and the asset prices displayed as they reflect all available information (Fama, 1970).

\section{Data and Methodology}

\subsection{Data Set}

Our data is sourced from DataStream (Thomson Reuters). After checking and comparing data for each variable, we found that some data were incomplete, especially for Islamic indices where Islamic stock markets did not exist or not operating yet in

Table 1. Conventional and Islamic indices in the focus markets

\begin{tabular}{lll}
\hline Country & Definition & SYmbol \\
\hline Turkey & MSCI TURKEY - PRICE INDEX & TURKL \\
\multirow{3}{*}{ Malaysia } & MSCI TURKEY IS - PRICE INDEX & TKISL \\
& MSCI MALAYSIA - PRICE INDEX & MALFL \\
Singapore & MSCI MALAYSIA ISLAMIC: I - PRICE INDEX & IMYIL \\
& MSCI SINGAPORE - PRICE INDEX & SINGL \\
Indonesia & MSCI SINGAPORE IS - PRICE INDEX & SNGIL \\
& MSCI INDONESIA - PRICE INDEX & INDFL \\
Thailand & MSCI INDONESIA ISLAMIC: I - PRICE INDEX & IIIL \\
& MSCI THAILAND - PRICE INDEX & THAFL \\
& MSCI THAILAND ISLAMIC: I - PRICE INDEX & ITFIL \\
\hline
\end{tabular}


Malaysia, Indonesia, and Thailand before 2002 and Singapore before 2007. Thus, in order to match the data of different variables in the same time period, we use daily data from 1 June 2007 to 30 October 2018. Our time period selection captures the variations in correlations among the indices, during the global financial crisis of 20082009, and post-crisis times. In addition, the use of recent daily data until October 2018 hopefully can provide more insightful information about the recent trends of the studied equities. To calculate indices returns we use the variation of daily price for each index: $\left(p_{t} / p_{t-1}\right)-1$, where $p$ is price index. Table 1 exhibits the sample indices (variables) used in this study for both conventional and Islamic (Shariah) stock markets.

\subsection{Methodology}

In our study, we use the MGARCH-DCC and wavelet transform estimators: the CWT as a second method to capture co-movement in time-frequency space, and the MODWT as a technique for robustness test.

\subsubsection{Multivariate GARCH - Dynamic Conditional Correlation (MGARCH-DCC)}

It is important for investors to know how volatilities and correlations between equity returns vary across time, along with their directions and size. Regarding time varying and time scale correlation, several studies have been done across stock market, relying on MGARCH-DCC estimators of portfolio diversification, such as Fantazzini (2009) who performed value at risk simulations. Aas and Berg (2009) tested dependence structures between financial assets. Righi and Ceretta (2011) investigated structural changes in volatility in European markets. Celık (2012) investigated contagion effects in the time of US subprime crisis for developed and emerging countries using MGARCH-DCC model.

Paramati, Gupta and Roca's (2012) findings stated that correlations vary in time, increase significantly and go back to their initial level after crisis. Furthermore, Ibrahim (2015) found in his study, that stock market integration relies on the intensity of foreign trade, which might have implications in decision making for investors in order to get portfolio diversification benefits. Narayan and Bannigidadmath (2016) found that the level of correlation between the markets impact the portfolio diversification benefits.

In similar studies, the multivariate GARCH models are largely employed to capture the dynamic relationship between the indices and to see how the variance and covariance of several markets move over time. DCC model helps in the estimation process, showing in a flexible way individual volatility of investors, so that it can be applied to portfolios of a large number of assets.

The auto regressive conditional heteroscedastic (ARCH) suggested by Engle (1982) was the first volatility model capturing time-varying conditional variances of time series based on previous information. Subsequently, Bollerslev (1986) came up with generalized ARCH (GARCH), taking into consideration past error terms and conditional variances. Later, and considering the assumption that the conditional correlations of different variables were constant, Bollerslev (1990) suggested a multivariate GARCHconstant conditional correlation (MGARCH-CCC). Finally, in order to be closer to the reality, Engle and Sheppard (2001) and Engle (2002) proposed the MGARCH-DCC (dynamic conditional correlation) as a significant improvement of the MGARCH-CCC. 
The main merits of DCC in relation with other time varying methods (such as Kalman filters and flexible least squares) is that it takes into account changes in both the mean (the first moment) and the variances (second moment) of the time series. The DCC model allows identifying changes (when and how they occur) in the interdependence between time series variables. In our study, we employ the MGARCHDCC model provided by Pesaran and Pesaran (2009) using Microfit software to compute the conditional cross-asset correlation following the formulas:

$$
\tilde{\rho}_{i j, t-1}(\varnothing)=\frac{q_{i j, t-1}}{\sqrt{q_{i i, t-1} q_{j j, t-1}}}
$$

where $q_{i j, t-1}$ are expressed by:

$$
q_{i j, t-1}=\underline{\rho}_{i j}\left(1-\emptyset_{1}-\emptyset_{2}\right)+\emptyset_{1} q_{i j, t-2}+\emptyset_{2} \tilde{r}_{i, t=1} \tilde{r}_{j, t=1}
$$

where $\rho_{i j^{\prime}}$ is the $(\mathrm{i}, \mathrm{j})^{\text {th }}$ unconditional correlation, $\emptyset_{1}$ and $\emptyset_{2}$ are parameters, verifying $\left(\emptyset_{1}+\emptyset_{2}\right)<1$ and $\tilde{r}_{i, t=1} \tilde{r}_{j, t=1}$ are the standardised asset returns.

\subsubsection{Continuous Wavelet Transform (CWT)}

The wavelet analysis is basically used in mathematics to divide a continuous-time function into wavelets, designed to overcome the limitations of the Fourier transform (Smimou, 2011). According to Dewandaru et al. (2014), the wavelet method is widely performed in disciplines like mathematics, geophysics, astronomy, climatology and medicine, and hence its employment in economics and finance related studies and researches is considered a new phenomenon due to its flexibility. Wavelet analysis can be divided into two: the discrete and the continuous. In our paper, we also use the continuous version of wavelet to address the third objective of this study.

A number of authors have employed CWT in economics and finance related studies such as Saiti et al. (2016) and Tiwari (2013). Norsworthy, Li and Gorener (2000) analysed stocks from the US market and found that the coefficients usually decrease as we move into higher scales. Madaleno and Pinho (2012) found a strong correlation between the stock market indices, and that high scales (or low frequencies) index returns reflect a significant and strong relation albeit heterogeneous across scales. In a similar vein, Rahim and Masih (2016) found that portfolio diversification benefits are not the same and vary across different investors holding periods.

The main merits of the CWT are that we do not need to address the number of wavelets (or time scales or holding periods): it can be produced automatically on the basis of the data length providing a large freedom in selecting the wavelets according to the length of the concerned date. In addition, the CWT approach contains both frequency and time having zero mean, and the level of decomposition of data is continuous and endogenous (compared to discrete wavelet transform - DWT). Furthermore, the CWT can address the correlations of two series in a two-dimensional form allowing easy identification and interpretation of the patterns of two series (Aguiar-Conraria \& Soares, 2011). Moreover, unlike the Fourier transform, CWT has the ability to construct a time-frequency representation of a signal that offers very good time and frequency localisation. 
In this paper, we follow the CWT method as applied by Aguiar-Conraria and Soares (2011) and Grinsted, Moore and Jevrejeva (2004). The CWT function $W_{x}(u, s)$ is obtained by projecting a mother wavelet $\psi$ into the examined time series $x(t) \in L^{2}(R)$ as follows:

$$
L^{2}(R): \quad W_{x}(u, s)=\int_{-\infty}^{\infty} x(t) \frac{1}{\sqrt{s}} \psi\left(\frac{t-u}{s}\right) d t
$$

where $\psi$ denotes the complex conjugate form, $\mathrm{u}$ is the time position or translation parameter controlling its location, $\mathrm{s}$ is the scale or dilatation parameter controlling the width of the wavelet (dilating the wavelet if $|s|>1$ or compressing it if $|s|<1$ ), and

$\frac{1}{\sqrt{s}}$ is a normalisation factor to make sure that the wavelet transforms are comparable across scale and time series.

Furthermore, concerning the interaction between two time series, or how $X$ and $Y$ are closely related by a linear transformation, we apply a wavelet coherence (a bivariate framework), defined as the squared absolute value of the smoothed cross wavelet spectra $W_{x y}(u, s)$, normalised by the product of the smoothest individual wavelet power spectra of each series, expressed as follows:

$$
R^{2}(u, s)=\frac{\left|S\left(s^{-1} W_{x y}(u, s)\right)\right|^{2}}{S\left(s^{-1}\left|W_{x}(u, s)\right|^{2}\right) S\left(s^{-1}\left|W_{y}(u, s)\right|^{2}\right)}
$$

where $S$ is a smoothing operator, $s$ is a wavelet scale, $W_{x}(u, s)$ is the continuous wavelet transform of the time series $X, W_{y}(u, s)$ is the continuous wavelet transform of the time series $Y, W_{x y}(u, s)$ is a cross wavelet transform of the two series $X$ and $Y$ (Madelano \& Pinho, 2012). The full and detailed mathematical equations of the model can be found in Gençay et al. (2001a; 2001b) and In and Kim (2013).

\subsubsection{Robustness Test: Maximum Overlap Discrete Wavelet Transformation}

In the literature, both DWT and MODWT are used to decompose the sample variance of a time series on a scale by scale basis, using its squared wavelet coefficients. However, MODWT model is better than the DWT estimator (Gallegati, 2008; Percival, 1995). The MODWT is a non-orthogonal transform, and it considers a non-dyadic length sample size, uses invariant translation (shifting the time series by an integer unit causes a shifting in the MODWT wavelet and scaling coefficients by the same amount), provides increased resolution of scales, and produces a better and efficient wavelet variance estimator. We, therefore, use the MODWT method as a robustness test in this study. Whitcher, Guttorp and Percival (2000) have extended the notion of wavelet variance for MODWT, introducing the definition of wavelet correlation and wavelet covariance between the two processes, their estimators and approximate confidence intervals. The MODWT technique provides exact correlation coefficient values existing between the different stock markets for each investment holding period while the CWT approach used earlier gives an approximative idea about the strength and directions of the correlation linkages between the stock markets across the time-scales. 
In order to define the magnitude of the linkage between the two series of observations $X$ and $Y$ using a scale-by-scale basis, the wavelet covariance is used. According to Gallegati (2008) and Gençay et al. (2001a, 2001b), the wavelet covariance at wavelet scale $j$ may be defined as the covariance between scale $j$ wavelet coefficients of $X$ and $Y$ as follows:

$$
\gamma_{X Y, j}=\operatorname{Cov}\left[\widetilde{\omega}_{j, t}^{X} \widetilde{\omega}_{j, t}^{Y}\right]
$$

An unbiased estimator of the wavelet covariance using MODWT is given by the equation below, after removing all wavelet coefficients affected by boundary conditions (Gallegati, 2008):

$$
\tilde{\gamma}_{X Y, j}=\frac{1}{\widetilde{N}} N-1 \sum_{t=L_{J-1}}^{N-1} \widetilde{\omega}_{j, t}^{X} \widetilde{\omega}_{j, t}^{Y}
$$

Then, the MODWT estimator of the wavelet cross-correlation coefficients for scale $\mathrm{j}$ and lag $\tau$ can be reached by using the wavelet cross-covariance $\tilde{\gamma}_{\tau X Y, j}$ and the square root of their wavelet variances $\tilde{\sigma}_{X, j}$ and $\tilde{\sigma}_{Y, j}$ as follows:

$$
\tilde{\rho}_{\tau, X Y, j}=\frac{\tilde{\gamma}_{\tau X Y, j}}{\tilde{\sigma}_{X, j} \tilde{\sigma}_{Y, j}}
$$

where the wavelet cross-correlation coefficients $\tilde{\rho}_{\tau, X Y, j}$ are between 0 and 1 (like other usual unconditional cross-correlation coefficients) and offer the lead/lag relationship between the two processes on a scale by scale basis.

After that and starting from spectrum $S_{\omega x, j}$ of scale $\mathrm{j}$ wavelet coefficients, the asymptotic variance $V_{j}$ of the MODWT-based technique of the wavelet variance (covariance) could be determined. Then we construct a random interval forming a 100(1-2p)\% confidence interval. Gallegati (2008) and Gençay, et al. (2001a) provided the formulas for an approximate 100(1-2p)\% confidence intervals for the MODWT estimator robust to non-Gaussianity for $\tilde{v}_{x, j}^{2}$ that can be checked. Accordingly, empirical evidence from the wavelet variance suggests that $N_{j}=128$ is a large enough number of wavelet coefficients for the large sample theory to be a good approximation (Gallegati 2008; Whitcher et al., 2000).

\section{Empirical Findings}

\subsection{Descriptive Statistics}

Descriptive statistics of returns for conventional and Islamic indices are displayed in Table 2. The results show that the standard deviation or the volatility of returns is the highest for $\mathrm{MSCl}$ Turkey index, followed by $\mathrm{MSCl}$ Turkey Islamic index and trailed by $\mathrm{MSCl}$ Indonesia Islamic index, MSCl Malaysia index and MSCl Malaysia Islamic index in descending order. This standard deviation shows absolute time independent volatility of the returns. As for the average returns represented by the mean, Table 2 shows that the highest returns among all other conventional and Islamic indices are provided by $\mathrm{MSCl}$ Turkey Islamic index followed by $\mathrm{MSCl}$ Indonesia indices, and the least returns 
Table 2. Descriptive statistics

\begin{tabular}{lccccccc}
\hline & Mean & Maximum & Minimum & Std.Dev. & Kurtosis & Skewness & Obs \\
\hline TURKL & 0.0003127 & 0.1356765 & -0.1020241 & 0.0166617 & 7.275844 & 0.0454480 & 2979 \\
TKISL & $\mathbf{0 . 0 0 0 4 9 5 9}$ & 0.1169464 & -0.0930603 & 0.0164086 & 7.103386 & 0.0227760 & 2979 \\
MALFL & 0.0000767 & 0.0482485 & -0.0973533 & $\mathbf{0 . 0 0 7 5 2 4 2}$ & 16.72269 & -0.7703559 & 2979 \\
IMYIL & 0.0001094 & 0.0460717 & -0.0936174 & $\mathbf{0 . 0 0 7 6 4 5 3}$ & 16.54923 & -0.8525658 & 2979 \\
SINGL & -0.0000117 & 0.0717395 & -0.0936467 & 0.0115955 & 10.14101 & -0.0066367 & 2979 \\
SNGIL & -0.0000106 & 0.1069037 & -0.079988 & 0.0117418 & 11.16497 & -0.0864625 & 2979 \\
INDFL & $\mathbf{0 . 0 0 0 4 3 0 5}$ & 0.1066647 & -0.1081796 & 0.0157786 & 9.093707 & -0.1262161 & 2979 \\
IIIQL & 0.0003269 & 0.0941885 & -0.1441472 & 0.0162716 & 9.436069 & -0.2919923 & 2979 \\
THAFL & 0.0003313 & 0.0984579 & -0.1313844 & 0.0139554 & 11.12442 & -0.2528163 & 2979 \\
ITFIL & 0.0002833 & 0.107577 & -0.1385442 & 0.0152213 & 9.759433 & -0.2328948 & 2979 \\
\hline
\end{tabular}

Notes: The grey shaded values represent the lowest values for mean and the highest ones for standard deviation and skewness of each index. The bold values represent the highest values for mean and the lowest values for standard deviation.

are provided by $\mathrm{MSCl}$ Singapore and $\mathrm{MSCl}$ Singapore Islamic indices. Across all indices, average returns are relatively small in comparison with standard deviation.

The skewness indicates the asymmetric property of a distribution and the related findings show that all returns are negatively skewed except for the returns of the $\mathrm{MSCl}$ Turkey and $\mathrm{MSCl}$ Turkey Islamic index returns, which means that the returns for these two indexes are not symmetric, leading to higher volatility and risk. The kurtosis measures the fastness of the distribution and indicates how the data is concentrated around the mean of the distribution.

\subsection{Findings Based on M-GARCH/DCC Method}

Unconditional correlation and volatilities are depicted in Tables 3 and 4 . If the unconditional volatility is near to 0 , it can be explained that the concerned index has the least volatility, whereas if the unconditional volatility is closer to 1 , it indicates higher volatility levels. The on-diagonal elements in Tables 3 and 4 represent the unconditional volatilities, while the off-diagonal elements represent the unconditional correlations of each asset.

In this study, we have ranked the returns of our ten indexes in Table 5 and we found out that all of them have very low unconditional volatilities ranging from 0.00753 to 0.01668 , which signifies, overall, that these ten returns on the ten stock indexes are less volatile.

We can observe from Table 5 that the MSCl Malaysia and $\mathrm{MSCl}$ Malaysia Islamic price indexes are respectively and relatively less volatile compared to the other eight indexes. This can be explained by the relative stability of Malaysia in response to the external shocks on conventional and especially Islamic capital markets (Abdullah et al., 2016; Rahim \& Masih, 2016). In fact, the relative stability of the Malaysian financial market has been built through the years, especially after the Asian financial crisis in 
Table 3. Unconditional correlations and volatilities (Turkey and all other indices)

\begin{tabular}{lccccccccc}
\hline & TURKL & MALFL & IMYIL & SINGL & SNGIL & INDFL & IIIQL & THAFL & ITFIL \\
\hline TURKL & 0.01668 & & & & & & & & \\
MALFL & 0.28741 & $\mathbf{0 . 0 0 7 5 3}$ & & & & & & & \\
IMYIL & $\mathbf{0 . 2 5 4 7 3}$ & 0.91951 & $\mathbf{0 . 0 0 7 6 4}$ & & & & & & \\
SINGL & 0.38616 & 0.52657 & 0.49623 & 0.01161 & & & & & \\
SNGIL & 0.35910 & 0.46917 & 0.44360 & 0.91442 & 0.01176 & & & & \\
INDFL & 0.30871 & 0.50038 & 0.48034 & 0.54928 & 0.50194 & 0.01582 & & & \\
IIIQL & 0.29319 & 0.45665 & 0.44783 & 0.50868 & 0.47265 & 0.91883 & 0.01630 & & \\
THAFL & 0.31360 & 0.44266 & 0.41357 & 0.56392 & 0.51510 & 0.48506 & 0.45630 & 0.01394 & \\
ITFIL & 0.27602 & 0.41112 & 0.39141 & 0.53366 & 0.49067 & 0.44540 & 0.43000 & 0.92395 & 0.01522 \\
\hline
\end{tabular}

Notes: The grey shaded (on-diagonal) values represent the highest volatility and bold on-diagonal values stand for the lowest volatility. The grey shaded (off-diagonal) values represent the highest correlation and the bold off-diagonal values represent the lowest correlation.

Table 4. Unconditional correlations and volatilities (Turkey Islamic and other Islamic indices)

\begin{tabular}{lcllll}
\hline & TKISL & IMYIL & SNGIL & IIIQL & ITFIL \\
\hline TKISL & 0.01640 & & & & \\
IMYIL & $\mathbf{0 . 2 4 6 5 1}$ & $\mathbf{0 . 0 0 7 6 4}$ & & & \\
SNGIL & 0.32355 & 0.44360 & 0.01176 & & \\
IIIQL & 0.26097 & 0.44783 & 0.47265 & 0.01630 & \\
ITFIL & 0.26976 & 0.39141 & 0.49067 & 0.43000 & 0.01522 \\
\hline
\end{tabular}

Notes: The grey shaded (on-diagonal) values represent the highest volatility and bold-on diagonal values stand for the lowest volatility. The grey shaded (off-diagonal) values represent the highest correlation and the bold off-diagonal values represent the lowest correlation.

Table 5. Ranks of the unconditional volatilities of the stock indexes

\begin{tabular}{llc}
\hline No. & \multicolumn{1}{c}{ Indices } & Unconditional volatility \\
\hline 1 & MSCI MALAYSIA - PRICE INDEX & $\mathbf{0 . 0 0 7 5 3}$ \\
2 & MSCI MALAYSIA ISLAMIC: I - PRICE INDEX & $\mathbf{0 . 0 0 7 6 4}$ \\
3 & MSCI SINGAPORE - PRICE INDEX & 0.01161 \\
4 & MSCI SINGAPORE IS - PRICE INDEX & 0.01176 \\
5 & MSCI THAILAND - PRICE INDEX & 0.01394 \\
6 & MSCI THAILAND ISLAMIC: I - PRICE INDEX & 0.01522 \\
7 & MSCI INDONESIA - PRICE INDEX & 0.01582 \\
8 & MSCI INDONESIA ISLAMIC: I - PRICE INDEX & 0.01630 \\
9 & MSCI TURKEY IS - PRICE INDEX & 0.01640 \\
10 & MSCI TURKEY - PRICE INDEX & 0.01668
\end{tabular}

Note: The grey shaded values represent the highest volatilities and the bold values represent the lowest volatilities. 
1997-1998, and the Malaysian reforms that followed to support, strengthen and protect the domestic financial sector from potential shocks. Therefore, with a relatively strong and stable financial sector, Malaysia could avoid dramatic damages in its economy and markets from the effects of the 2007-2008 global financial crisis, along with a sufficient liquidity in the financial system and minor existence of assets related to subprime bubbles (Ibrahim, 2010). Hamidi, Khalid and Karim (2018) have argued that the Malaysian stock market is quite efficient when it comes to its adjustment speed after a shock, needing three quarters only before regaining its stability level.

With regard to the off-diagonal elements showing the unconditional correlations as presented in Table 3 and Table 4, it is observed that MSCl Turkey stock index returns have the highest correlation with $\mathrm{MSCl}$ Singapore index returns among the other returns of the seven indexes which is +0.38616 . Similarly, from Table 4, we can see that $\mathrm{MSCl}$ Turkey Islamic Stock index returns have the highest correlation with $\mathrm{MSCl}$ Singapore Islamic stock returns among the other returns of the three indexes, which is +0.32355 . These positive correlations of $38 \%$ between Turkish and Singapore stock indexes, and $32 \%$ between Turkish Islamic and Singapore Islamic stock indexes, respectively, are considered to be moderate and not too high. These high correlations linkages are not much of a surprise since Singapore is ranked as the 46th largest trading partner of Turkey in 2016, with total bilateral trade in goods of $\mathbf{\$} \$ 1.41$ billion, backed by bilateral trade plans to reach $\$ 2$ billion in trade volume by the end of 2018, according to the Turkish Economy Minister Nihat Zeybekci (Hurriyet Daily News, 2017). In fact, referring to the Turkey-Singapore Free Trade Agreement (TRSFTA) signed in November 2015 between the two countries, Turkey will eliminate tariffs for Singapore's exports on more than $95 \%$ of all tariff lines while Singapore will grant duty-free access for all Turkish products.

In contrast, both $\mathrm{MSCl}$ Turkey and $\mathrm{MSCl}$ Turkey Islamic stock indexes have the weakest correlation with the MSCI Malaysia Islamic stock index returns, i.e. 0.25473 and 0.24651 , respectively. It can be suggested that there are more chances of diversification benefits for Turkish investors (both conventional and Shariah-compliant) by including $\mathrm{MSCl}$ Malaysia Islamic stock index in their portfolio as compared to the other stock indexes.

In what follows, we examine the dynamic conditional correlations which capture the time-varying properties in the volatilities and the correlations. Figures 1-4 illustrate the results of this exercise.

Figure 1 illustrates the conditional volatilities of Turkish stock index returns along with all the other conventional and Islamic stock index returns. Figure 2 illustrates the conditional volatilities of Turkish Islamic stock index returns with other Islamic stock returns. From the observation across the eleven years (June 29, 2007 to October 31, 2018) in Figures 1 and 2, we notice that most equities are likely to move approximatively in simultaneous patterns except during the 2008 global financial crisis. It is relevant to note that the highest volatility of conventional and Islamic stock indexes is observed during the global financial crisis in 2008.

There seems to be a high convergence of volatilities among all indexes, which indicates a higher financial integration between these indexes. Usually higher financial integration between stock returns is unfavourable for investors and portfolio managers 


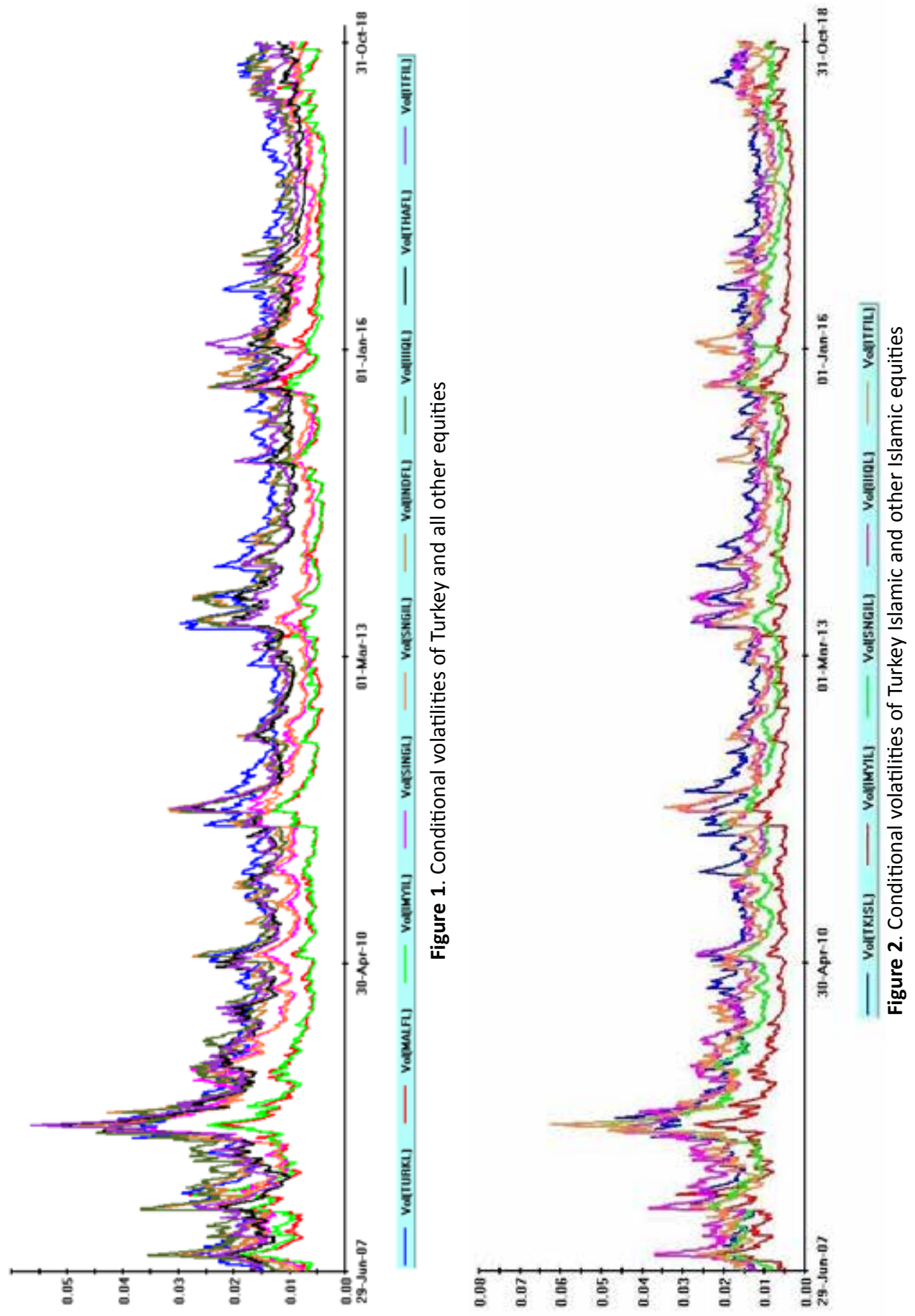


since it means that they have fewer chances to gain benefits from portfolio diversification (Kabir, Bacha, \& Masih, 2013). We notice that Turkey conventional and Islamic indices are extremely volatile compared to all conventional and Islamic indexes. In contrast, Malaysian conventional and Islamic stock indexes have the lowest volatility level during that period. In the case of Singapore, we can see that the volatilities of its conventional and Islamic stock indexes are high during the period of crisis, before gradually returning to the volatility levels of Malaysia indexes starting from 2010. The remaining indexes (Indonesia conventional, Indonesia Islamic, Thailand conventional and Thailand Islamic) are fairly moderate and not too volatile. To a certain extent, these conditional volatility results confirm our previous results shown in Table 5 . We may conclude from Figures 1 and 2 that it is very risky to invest in Turkey conventional and Islamic indexes because they are far more volatile than other indexes. We may also conclude that Malaysia indexes (conventional and Islamic) are relatively safe compared to the rest of equity indexes. Again, the results consistently confirm our previous results shown in Table 5.

Next, we plot conditional correlations between Turkey and all other conventional and Islamic indexes in Figure 3. Figure 4 illustrates the conditional correlations between Turkey Islamic indexes and other Islamic indexes.

Figures 3 and 4 show that Turkey and all other stock index returns are moving quite closely together especially after the global financial crisis of 2008. In fact, during the period of crisis, we can observe from both figures that the correlations of Turkey stock index returns with Singapore stock index returns were the highest during the crisis, showing an increasing pattern that is quite distant from other correlations linking Turkey with other countries' stock index returns which were in a downward trend before starting to increase again in 2009 after the crisis.

Figure 3 shows that Turkey indices have the highest correlation with Singapore conventional and Singapore Islamic stock index returns respectively. A weak correlation is observed between Turkey stock index returns and Malaysia Islamic stock index returns, as well as for Turkey index with Thailand Islamic index. From Figure 4 we can observe that Turkey Islamic index is highly correlated with Singapore Islamic index, and that the lowest correlation is between Turkey Islamic index and Malaysia Islamic index (except for the period of 2017 where the correlation of Turkey Islamic and Malaysia Islamic indices was high and close to the correlation between Turkey Islamic and Singapore Islamic indices).

Again, all these results from Figures 3 and 4 are consistent with the ones of unconditional correlations in Table 5. It can be seen that stock indexes of Singapore, both conventional and Islamic, are not suitable for Turkish conventional and Islamic investors to include them in their portfolio, which can be attributed to some underlying factors. Singapore is actually the second large buyer of Turkey's exports in the AsiaPacific region, after China. Turkey and Singapore are both important hubs in their respective regions: Turkey is considered as a gateway to Europe, Middle East and Central Asia markets, while Singapore is a key entry to Southeast Asia. According to Turkish Statistical Institute (TSI), the annual volume trade between Turkey and Singapore increased from US\$ 200 million ten years ago to reach the volume level of US\$ 700 million in 2015. 

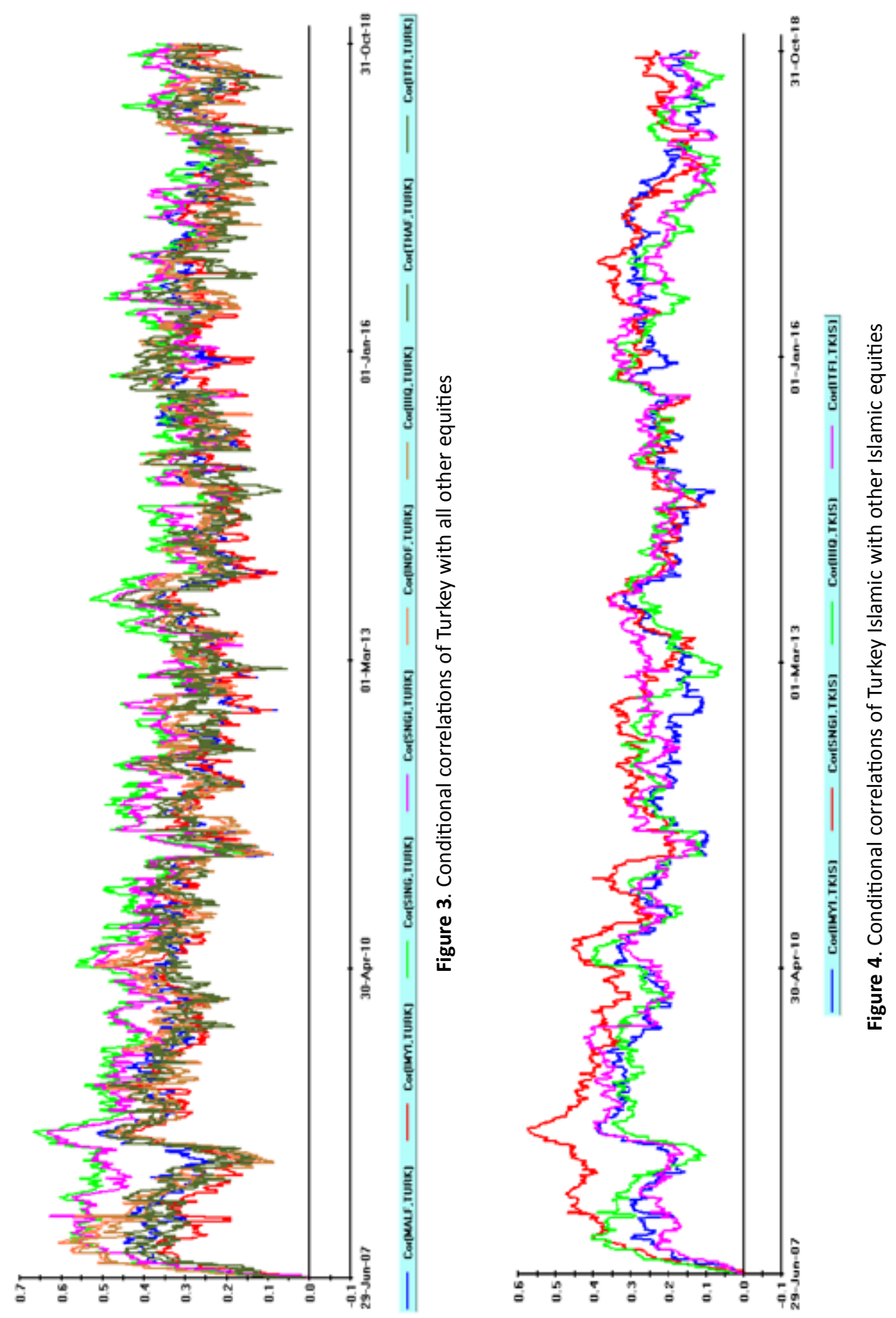
The two nations have already set commercial and economic relations, such as the Singapore-Turkey Air Transport Agreement, the Singapore-Turkey Investment Promotion and Protection Agreement, the Turkey-Singapore Investment Avoidance and Double Taxation Agreement, and the memorandum of understanding between the Singapore Exchange (SGX) and the Borsa Istanbul. Thus, around 60 Turkish companies have been registered in Singapore since 2008 for investment purposes and opportunities in Southeast Asia. However, it can be suggested from here that Turkish investors are better off investing in Malaysia conventional and Malaysia Islamic stock markets, to gain more diversification benefits compared to all other stock indexes. Similarly, Turkey Shariahcompliant investors should invest in the Malaysian Islamic stock market in order to gain more diversification opportunities. The foreign direct investments of Turkey in Malaysia reached US\$127 million in 2015 and this could be linked to the Malaysia-Turkey Free Trade Agreement (MTFTA) signed in 2014 in Ankara. However, compared to the strong existing ties between Turkey and Singapore, Turkish investors do still have some years to go in benefiting from portfolio diversification returns in the Malaysian stock markets.

\subsection{Findings Based on Continuous Wavelet Transform (CWT)}

In this section, continuous wavelet transform analysis is done to investigate the effects on portfolio diversification gains across different holding periods. Thus, we will focus on the wavelet coherence methodology. The results from wavelet coherence, to a certain extent, augment our previous MGARCH-DCC results.

The results for variables under review are presented from scale 1 (one day) up to scale 10 (1024 days). The lower horizontal axis represents the time in trading days, while the vertical axis refers to the different holding period. The curved line represents the $5 \%$ significance level obtained from the Monte Carlo simulations. The figure uses colour codes for strength of correlations, ranging from black (low correlations) to white (high correlations). When the vector arrows point to the right, it means that the indexes are in phase (have positive correlation), however, when they point to the left, it means that the indexes are out of phase (have negative correlation). Moreover, when the vector arrows point to the right and down it means that the first series is leading, whereas if they point to right and up, it means that the second series is leading (Madaleno \& Pinho, 2010). In this study, MSCl Turkey is considered as the first series in the first group of wavelet coherence diagrams, while $\mathrm{MSCl}$ Turkey Islamic is considered as the first series in the second group of wavelet coherence diagrams. High frequency correlation may spread information about short-run market linkages such as cross-border trading, market sensitiveness or panic, liquidity preferences, etc. However, low frequency correlation could be associated with linkages concerning the real economy as well, as it may be reflecting a long-run relationship of concerned stock markets. In fact, Bodart and Candelon (2009) and Orlov (2009) have linked high and low frequencies with contagion and interdependence. In addition, according to Bekaert, Harvey and $\mathrm{Ng}$ (2005), a positive causality of market integration could be explained by market dependence. In other words, when stock markets are closely integrated, the explanation would refer to common local and regional factors, where a local market return is determined by its covariances with other markets of the same region. 
Figures 5, 6, 7 and 8 show the continuous wavelet transform and phase difference of Turkey stock index returns with stock index returns of Malaysia, Malaysia Islamic, Singapore, Singapore Islamic, Indonesia, Indonesia Islamic, Thailand and Thailand
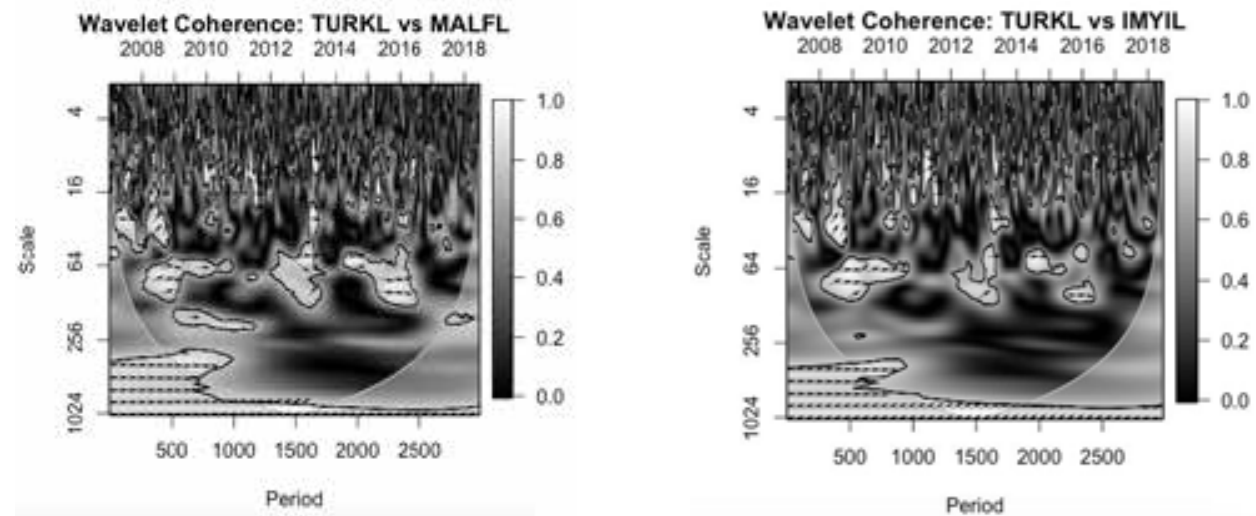

Figure 5: Continuous Wavelet Transform - Turkey vs Malaysia and Malaysia Islamic
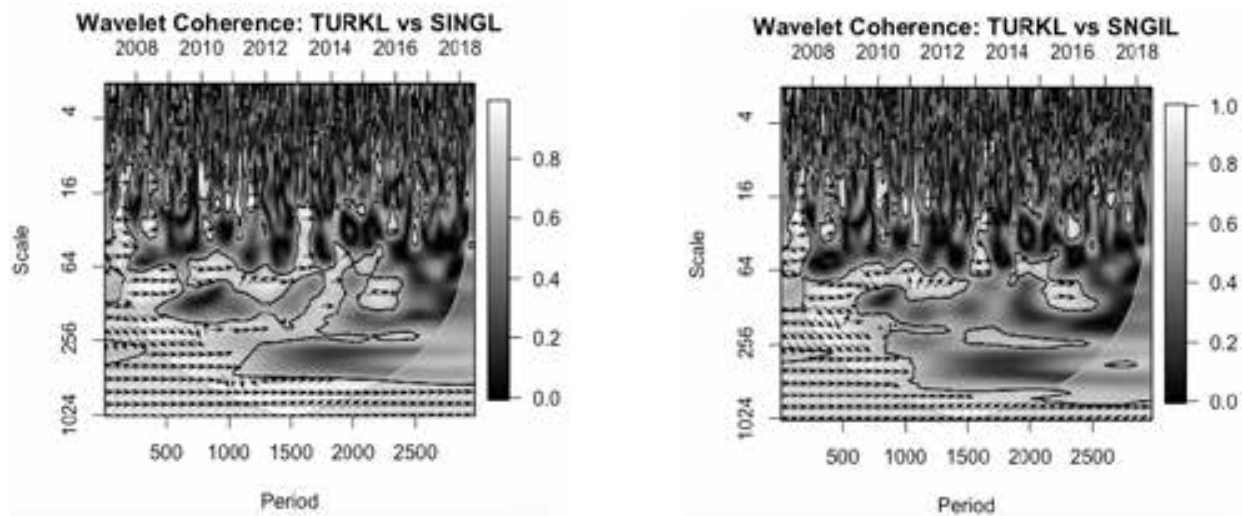

Figure 6: Continuous Wavelet Transform - Turkey vs Singapore and Singapore Islamic
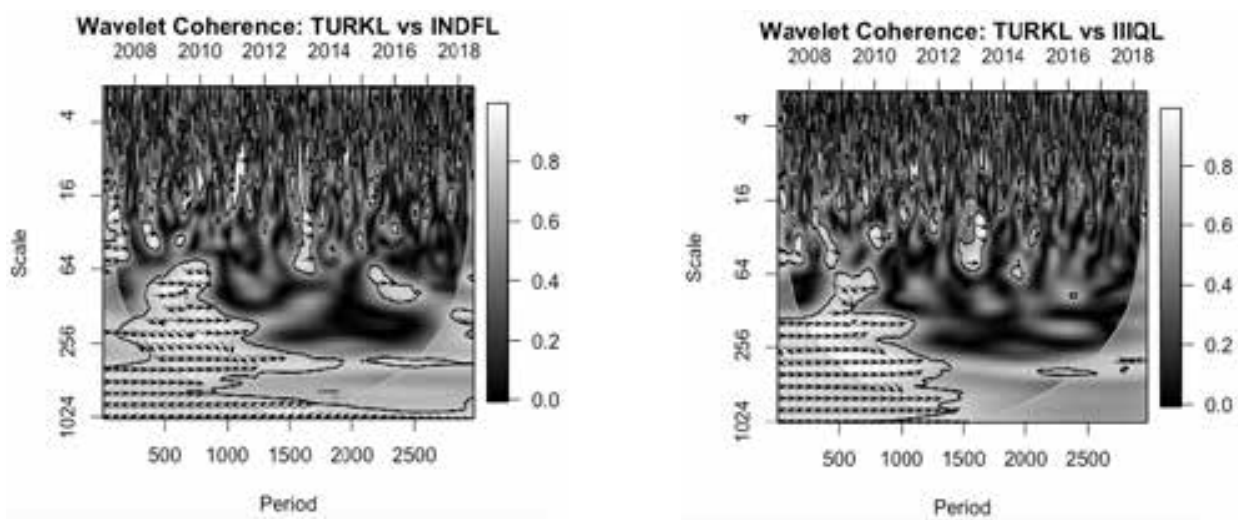

Figure 7: Continuous Wavelet Transform - Turkey vs Indonesia and Indonesia Islamic 

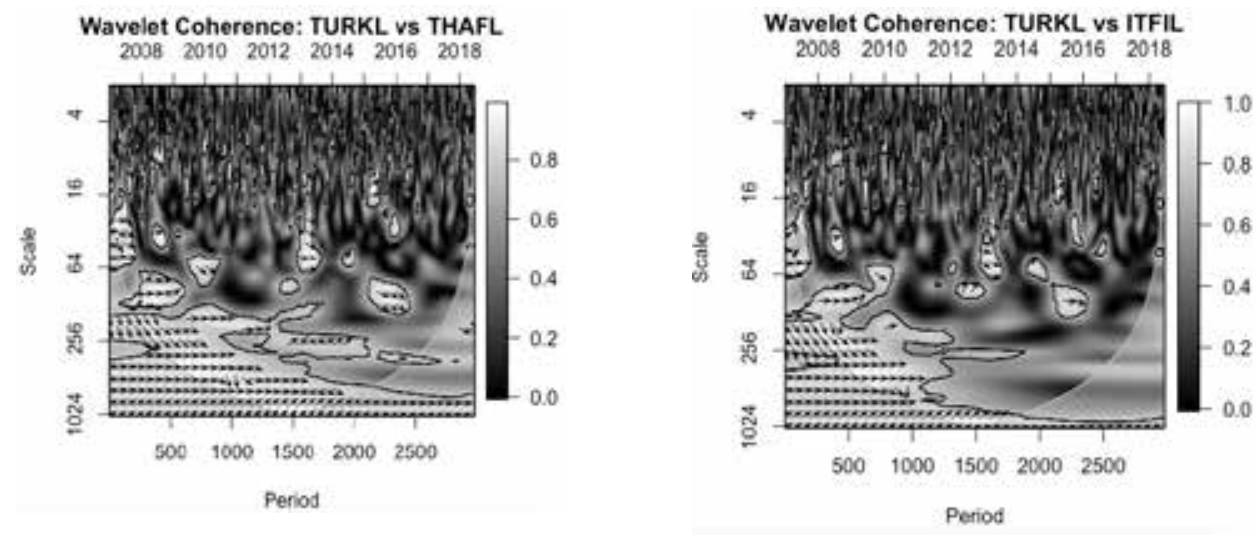

Figure 8: Continuous Wavelet Transform - Turkey vs Thailand and Thailand Islamic

Islamic, respectively. Figure 9 illustrates the continuous wavelet transform and phase difference of Turkey Islamic stock index returns with stock index returns of Malaysia Islamic, Singapore Islamic, Indonesia Islamic and Thailand Islamic, respectively.

From Figures 5, 6, 7 and 8, apparently the correlations between Turkey index with Malaysia, Malaysia Islamic, Singapore, Singapore Islamic, Indonesia, Indonesia Islamic, Thailand and Thailand Islamic indexes are relatively weak for very short holding periods (2-4, 4-8 and 8-16 days). But, the returns of Singapore and Indonesia (for both conventional and Islamic) and Thailand indexes have a stronger correlation relative to stock index returns of Malaysia, Malaysia Islamic and Thailand Islamic. This is also true during the period of the global financial crisis of 2008-2009 (indicated by observation points 0 to 1000$)$.

Considering now the selected conventional and Islamic indexes, we can observe that Islamic stock market index returns are performing slightly better than their related conventional indexes in mitigating the negative impacts during the financial crisis and the post-crisis periods, as illustrated by relatively lower correlations with Turkey stock index returns (observation points 500 to 2000). Therefore, if Turkish conventional investors want to invest in these short time periods (2-4, 4-8 and 8-16 days), investing in indexes of Malaysia, Malaysia Islamic and Thailand Islamic represent better options.

Moving on to the medium investment horizons of 16-32, 32-64 and 64-128 days, the above figures show strong correlations of Turkey with all the remaining conventional and Islamic indexes, especially during the global financial recession of 2008-2009 and the post-crisis period (observation points 0 to 1700). It is noteworthy to mention that the highest correlations are observed between Turkey stock index returns and Singapore (conventional and Islamic), while the lowest correlations are between Turkey indexes and Malaysia (conventional and Islamic) indexes. This implies that medium term Turkish investors may want to avoid investing in the Southeast Asian stock indexes, as it would be difficult to experience benefits from portfolio diversification in the medium investment horizons.

Relating to the long-run investment horizons of 128-256, 256-512 and 512-1024 days, low correlation levels are observed between Turkey and Malaysia (conventional 
and Islamic) indices, except for the financial crisis period (observation points 0 to 1000) where the correlation was high. An interesting finding is that Indonesia Islamic stock index returns has low correlation with Turkey indices for the investment timescale of 128-256 days (after the financial crisis period). All other indices show very high correlations with the Turkey index for long stock holding periods. Concerning the arrows indicating the phases of the variables, the direction of most arrows in the higher time-scales or longer investment periods indicates that the relationship between Turkey returns and all other index returns are in place most of the time. Therefore, Turkish conventional investors for long-run holding periods (128-256, 256-512 and 512-1024 days) would likely want to invest in indices of Malaysia and Malaysia Islamic rather than the other indices in order to benefit from portfolio diversification.

Having discussed the CWT of Turkey conventional index with all other indexes, we move our analysis to the correlations of Turkey Islamic index returns with other Islamic indexes. As depicted in Figure 9, the correlations between Turkey Islamic index with Malaysia Islamic, Singapore Islamic, Indonesia Islamic and Thailand Islamic indexes are relatively weak for very short holding periods (2-4, 4-8 and 8-16 days). However, the returns of Singapore Islamic and Indonesia Islamic have a stronger correlation compared
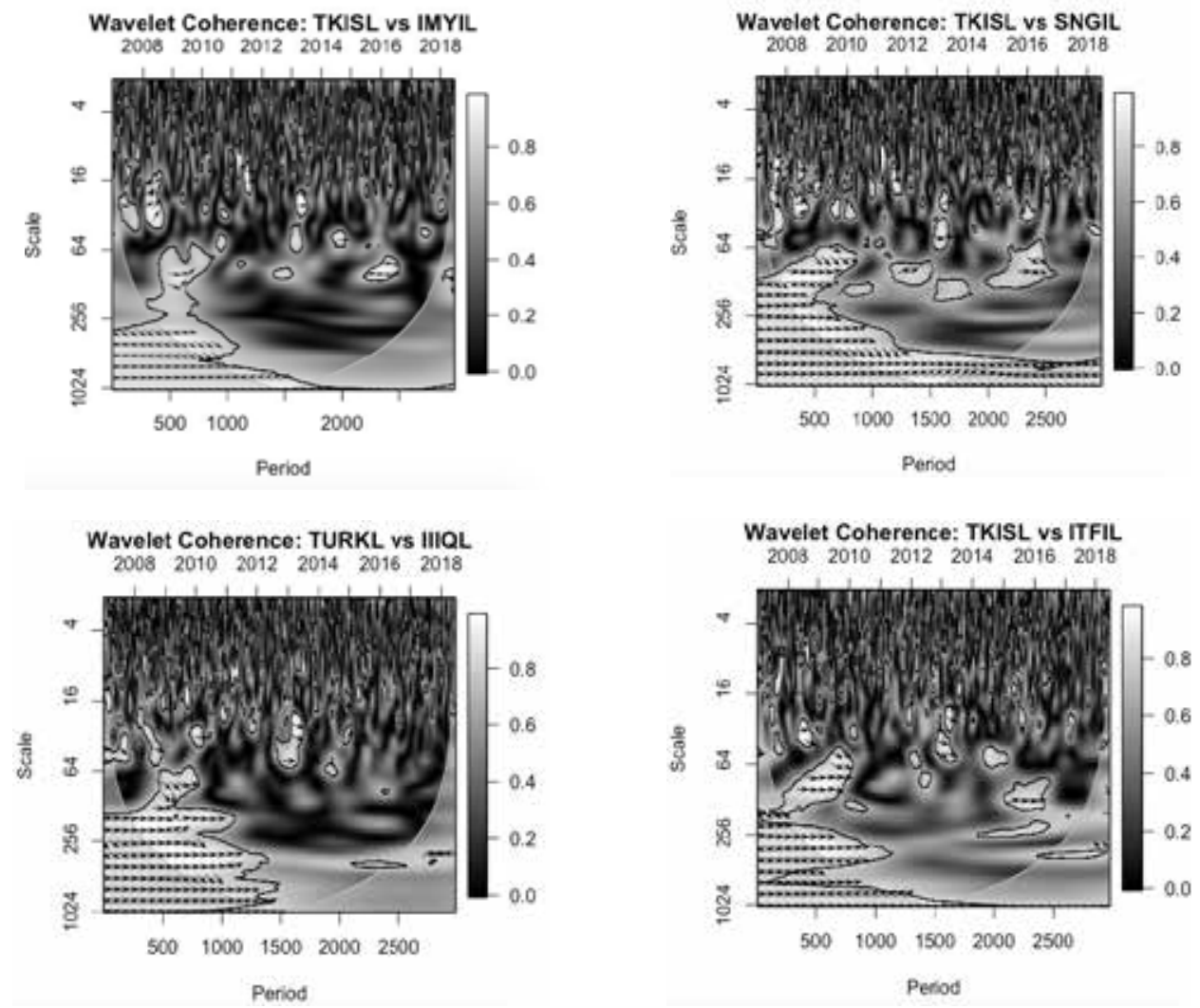

Figure 9: Continuous Wavelet Transform - Turkey Islamic vs all other Islamic indices 
to other Islamic stock index returns. This is also the case when we go down and observe the period of the global financial crisis of 2008-2009 (indicated by observation points 0 to 1000). Therefore, if Turkish Islamic investors want to invest in these short time periods (2-4, 4-8 and 8-16 days), investing in Islamic stock indices other than Singapore and Indonesia is a more preferred option.

Moving on to medium investment horizons of 16-32, 32-64 and 64-128 days, Figure 9 depicts the strong correlations of Turkey Islamic with all the other Islamic indexes, especially during the global financial crisis of 2008-2009. However, the highest correlations are observed between Turkey Islamic and Singapore Islamic stock index returns, while the lowest correlations are between Turkey Islamic and Malaysia Islamic indices. From here it could be said that medium-term Turkish Islamic investors may want to avoid investing in the stock indexes of Southeast Asian stock indexes (except Malaysia Islamic), as it would be difficult to expect gains from portfolio diversification.

As for the long-run investment horizons of 128-256, 256-512 and 512-1024 days, low correlation levels are observed between Turkey Islamic and Malaysia Islamic indices, except during the financial crisis period (observation points 0 to 1000), given the high correlation. An interesting observation from Figure 9 is that Indonesia Islamic stock index returns have low correlation with Turkey Islamic indexes for the holding period of 128-256 days (after the financial crisis period). The other indexes of Singapore Islamic and Thailand Islamic show high correlations with Turkey Islamic index for the long stock investing periods. The direction of most arrows in the longer investment periods indicates that the relationship between Turkey Islamic returns and all other Islamic index returns is in place most of the time. Therefore, Turkish Islamic investors for long-run holding periods (128-256, 256-512 and 512-1024 days) would likely want to invest in the Malaysia Islamic stock market rather than the other Islamic indexes, to receive portfolio diversification benefits.

Overall, the wavelet transformations have helped us understand the potential benefits of international portfolio diversification for Turkish conventional and Shari'ahcompliant investors with different investment horizons.

\subsection{Robustness and Validation of Results - MODWT}

To ensure that the results from the CWT analysis are robust, a MODWT is applied to our original data set consisting of return series for all ten stock indexes. In MODWT, we have eight scales (2-4 days, 4-8 days, 8-16 days, 16-32 days, 32-64 days, 64-128 days, 128-256 days and 256-512 days). The correlations between the Turkey stock market returns with the index returns of the conventional and Islamic Southeast Asian stock returns are shown in Table 6. Table 7 exhibits the correlations between the Turkey Islamic stock returns and the Southeast Asian Islamic stock returns. The results of MODWT return series are generated using RStudio structural programming software.

Interestingly, the results of Table 6 are consistent with the ones obtained from the earlier CWT analysis. The stock indexes of Singapore (both conventional and Islamic) seem to be providing opportunities of portfolio diversification that are not favourable to the Turkish investors in long investment horizons, where the correlations are seen 
to be strong. At the same time, we can observe from above that, for holding periods of 2-4 and 4-8 days, stock indexes of Malaysia, Indonesia and Thailand offer good opportunities for portfolio diversification for Turkish investors. However, Malaysia seems to outperform the other indexes for holding periods of 256-512 days, offering the best portfolio diversification opportunities for Turkish investors compared to all other countries that show high correlation. In the case of Malaysia, it is important to emphasise

Table 6. Wavelet correlations of Turkey stock market returns with all other index returns MODWT transformation

\begin{tabular}{lcccccccc}
\hline $\begin{array}{l}\text { MODTW } \\
\text { Scaling }\end{array}$ & MALFL & IMYIL & SINGL & SNGIL & INDFL & IIIQL & THAFL & ITFIL \\
\hline 2-4 Days & 0.1592796 & 0.1351395 & 0.2975352 & 0.2748237 & 0.1941644 & 0.1931901 & 0.2300853 & 0.2009784 \\
4-8 Days & 0.3661351 & 0.3175365 & 0.4060733 & 0.3726845 & 0.3192819 & 0.2993924 & 0.3459887 & 0.2981887 \\
8-16 Days & 0.3958291 & 0.3566923 & 0.4908066 & 0.4769098 & 0.4922936 & 0.4705903 & 0.4068293 & 0.3427803 \\
16-32 D & 0.3958291 & 0.3990187 & 0.4954357 & 0.5006141 & 0.4335374 & 0.4009099 & 0.3597943 & 0.3378822 \\
32-64 D & 0.4001489 & 0.3804516 & 0.5261159 & 0.5024807 & 0.4796016 & 0.4554433 & 0.4542936 & 0.4394017 \\
64-128 D & 0.6699817 & 0.6521451 & 0.8083418 & 0.7652423 & 0.6033726 & 0.5278571 & 0.6041578 & 0.5801457 \\
128-256 D & 0.4090797 & 0.2860735 & 0.6924611 & 0.6589479 & 0.4887248 & 0.4583238 & 0.7000809 & 0.5892771 \\
256-512 D & 0.1320636 & 0.1551186 & 0.6047726 & 0.4767733 & 0.7282020 & 0.6665852 & 0.7515230 & 0.6289693 \\
\hline
\end{tabular}

Notes: Correlations more than 0.6 are arbitrarily considered to be strong (Najeeb et al., 2015). The values between 0.38 and 0.6 indicate moderate correlation are highlighted in light grey. The rest highlighted in dark grey indicate high correlation.

Table 7. Wavelet correlations of Turkey Islamic stock market returns with other Islamic index returns - MODWT transformation

\begin{tabular}{lcccc}
\hline MODTW Scaling & IMYIL & SNGIL & IIIQL & ITFIL \\
\hline 2-4 Days & 0.138222870 & 0.2474331 & 0.1649374 & 0.1902200 \\
4-8 Days & 0.305569704 & 0.3120701 & 0.2564255 & 0.2864474 \\
8-16 Days & 0.315904621 & 0.4443338 & 0.4019598 & 0.3509738 \\
16-32 Days & 0.406475076 & 0.4882393 & 0.4331636 & 0.3497062 \\
32-64 Days & 0.351187864 & 0.3980757 & 0.4373381 & 0.4626338 \\
64-128 Days & 0.566279300 & 0.6577905 & 0.3742396 & 0.5111184 \\
128-256 Days & 0.208995564 & 0.6263743 & 0.2310911 & 0.6257560 \\
256-512 Days & -0.001020414 & 0.3380210 & 0.5311147 & 0.4134639 \\
\hline
\end{tabular}

Notes: Correlations more than 0.6 are arbitrarily considered to be strong (Najeeb et al., 2015). The values between 0.38 and 0.6 indicate moderate correlation are highlighted in light grey. The rest highlighted in dark grey indicate high correlation. 
here that Malaysia Islamic index offers better diversification opportunities for Turkish investors compared to Malaysia conventional index, especially for the time-scale of 128256 days, which show a low correlation, while all other indexes bear high correlations.

On the investment horizon of 64-128 days, it seems that all indexes are showing high correlations exceeding 0.6 and reaching 0.8 in the case of Singapore, from which one may conclude that Turkish investors would better not invest in any of these indexes for this specific holding period. However, for the time-scales of 8-16 and 16-32 days, Turkish investors would better invest in Thailand stock indexes rather than others. Another interesting finding from Table 6 is that Thailand Islamic stock index is the only one showing the lowest correlations during the continuous investment horizons of 2-4, 4-8, 8-16 and 16-32 days.

These findings are also consistent with the CWT results. In fact, all Islamic indexes show low correlations with the Turkish Islamic index for holding periods of 2-4 and 4-8 days. Thailand Islamic index offers low and continuous correlations for time-scales of 2-4, 4-8, 8-16 and 16-32 days. Turkish Islamic investors may prefer Indonesian Islamic stocks for the holding period of 64-128 days. For long-term holding periods, Malaysia Islamic and Indonesia Islamic stock indexes show low correlations with Turkey Islamic index for 128-256 days, in addition to the time scale of 256-512 days for Malaysia Islamic index. Although Singapore Islamic index shows high correlations with the Turkish Islamic index for the holding periods of 64-128 and 128-256 days surpassing the level of 0.62 , the index offers low correlation with Turkey Islamic index for 256-512 days' timescale, along with Malaysia Islamic index.

Overall, it can be concluded from both Tables 6 and 7 that Malaysia and Malaysia Islamic stock indexes offer better portfolio diversifications for Turkish investors (conventional and Islamic) for short holding periods of 2-4 and 4-8 days, and the long time-scales of 128-256 and 256-512 days. However, Turkish investors (conventional and Islamic) would rather avoid investing in stock indexes of their "new" trading partner Singapore, especially for the investment horizons of 64-128 and 128-256 days. As for Thailand Islamic index, Turkish investors (conventional and Islamic) would gain portfolio diversification benefits for the short and continuous time-scales of 2-4, 4-8, 8-16 and 16-32 days. Thus, the findings from the MODWT analysis are in line with ones obtained under the CWT analysis.

\section{Conclusion}

Our findings suggest that it is advisable for Turkish conventional and Islamic investors to avoid investing in Singapore and Singapore Islamic stock markets as they show high correlations linkages and thus offer very low diversification benefits. In contrast, the least correlations are obtained with Malaysia and Malaysia Islamic stock return indices, meaning that Turkish conventional and Islamic investors have great portfolio diversification benefits to gain from their investments in Malaysia.

The study finds that Turkish investors (conventional and Islamic) who have allocated their investments in Singapore equities would likely not gain diversification benefits in almost all investment horizons. At the same time, investing in stock indexes of Indonesia and Thailand offers moderate diversification benefits overall. The findings show also 
that Turkish conventional and Islamic investors would rather invest in Malaysian equities for short-run investment horizons up to 16 days, as well as for long-term investment periods exceeding 128 days. In addition, Turkish investors could gain diversification benefits from investing in Thailand Islamic equities in short-run holding periods up to 16 days. Speaking of the medium-run implications for all stock indices, stock holding periods from 16 days until 128 days offer minimal benefits of portfolio diversification, which means that Turkish investors would better avoid investing in all the equities in medium-run holding periods. It is advisable for Turkish investors to avoid long-run investment horizons for equities in Singapore, Indonesia and Thailand as they show high correlations and thus offer lower diversification benefits for investment horizons exceeding 128 days. It is noteworthy that, during the global financial crisis of 2008-2009, all the stock markets were severely impacted with high volatility and highly correlated indexes across the board, sparing hardly any space for diversification benefits.

Overall, the results of this study support the previous empirical literature that there are limited long-term diversification benefits compared to the short-term ones for international investors in the Southeast Asian stock markets (e.g. De Gooijer \& Sivarajasingham, 2008). Malaysia may well be considered as a safe haven for Turkish conventional and Shariah-compliant investors, especially in short-term investment periods, as well as for long-run investment horizons, as it offers better risk mitigation and higher portfolio diversification compared to other Southeast Asian countries and stock markets.

The findings of this study are expected to have significant implications for Turkish investors and portfolio managers. The understanding of returns correlations among stock market indices is crucial for diversifying portfolios among different markets so as to obtain higher risk-adjusted returns (Paramati et al., 2012). Our results are also important for the Turkish monetary authorities on policies relating to equity investments at different investment periods and horizons. Turkey's vision and hope of becoming one of the top ten economies of the world by 2023 hinges critically on strengthening its economic and business linkages with emerging economies, including those in Southeast Asia. Thus, Turkey's performance, investment outcomes and benefits from the Southeast Asian region would depend on Turkish investors, portfolio managers and government agencies in their choices and policies.

\section{References}

Aas, K., \& Berg, D. (2009). Models for construction of multivariate dependence - a comparison study. The European Journal of Finance, 15(7-8), 639-659. https://doi.org/10.1080/ 13518470802588767

Abderrezak, F. (2008). The performance of Islamic equity funds: A comparison to conventional, Islamic and ethical benchmarks. Unpublished paper.

Abdullah, A.M., Saiti, B., \& Masih, M. (2016). The impact of crude oil price on Islamic stock indices of South East Asian countries: Evidence from MGARCH-DCC and wavelet approaches. Borsa Istanbul Review, 16(4), 219-232. https://doi.org/10.1016/j.bir.2015.12.002

Achsani, N., Effendi, J., \& Abidin, Z. (2007). Dynamic interdependence among international Islamic stock market indices: Evidence from 2000-2007. In Proceedings of the international conference of the Islamic capital markets, Jakarta, Indonesia. 
Aguiar-Conraria, L., \& Soares, M.J. (2011). Oil and the macroeconomy: Using wavelets to analyze old issues. Empirical Economics, 40(3), 645-655. https://doi.org/10.1007/s00181-010-0371-x

Aiello, S., \& Chieffe, N. (1999). International index funds and the investment portfolio. Financial Services Review, 8(1), 27-35. https://doi.org/10.1016/S1057-0810(99)00029-3

Ajmi, A.N., Hammoudeh, S., Nguyen, D.K., \& Sarafrazi, S. (2014). How strong are the causal relationships between Islamic stock markets and conventional financial systems? Evidence from linear and nonlinear tests. Journal of International Financial Markets, Institutions and Money, 28(January), 213-227. https://doi.org/10.1016/j.intfin.2013.11.004

Ali, H., \& Masih, M. (2016). Evidence of cross-country portfolio diversification benefits: The case of Saudi Arabia (Working paper). https://doi.org/10.13140/RG.2.1.1599.9608

Aziz, H., \& Kurniawan, T. (2007). Modelling the volatility of the Sharia index: Evidence from the Kuala Lumpur Sharia index and Jakarta Islamic index. In Proceedings of the international conference of the Islamic capital markets, Jakarta, Indonesia.

Bekaert, G., Harvey, C.R., \& Ng, A. (2005). Market integration and contagion. The Journal of Business, 78(1), 39-69. https://doi.org/10.1086/426519

Black, F., \& Litterman, R. (1992). Global portfolio optimization. Financial Analysts Journal, 48(5), 28-43. https://doi.org/10.2469/faj.v48.n5.28

Bodart, V., \& Candelon, B. (2009). Evidence of interdependence and contagion using a frequency domain framework. Emerging Markets Review, 10(2), 140-150. https://doi.org/10.1016/j. ememar.2008.11.003

Bodie, Z., Kane, A., \& Marcus, A.J. (2008). Investments (10th ed.). New York, NY: McGraw-Hill Education.

Bollerslev, T. (1986). Generalized autoregressive conditional heteroskedasticity. Journal of Econometrics, 31(3), 307-327. https://doi.org/10.1016/0304-4076(86)90063-1

Bollerslev, T. (1990). Modelling the coherence in short-run nominal exchange rates: A multivariate generalized ARCH model. The Review of Economics and Statistics, 72(3), 498-505. https://doi. org $/ 10.2307 / 2109358$

Buriev, A.A., Dewandaru, G., Zainal, M.P., \& Masih, M. (2018). Portfolio diversification benefits at different investment horizons during the Arab uprisings: Turkish perspectives based on MGARCH-DCC and wavelet approaches. Emerging Markets Finance and Trade, 54(14), 32723293. https://doi.org/10.1080/1540496X.2017.1362555

Celık, S. (2012). The more contagion effect on emerging markets: The evidence of DCCGARCH model. Economic Modelling, 29(5), 1946-1959. https://doi.org/10.1016/j. econmod.2012.06.011

Click, R.W., \& Plummer, M.G. (2005). Stock market integration in ASEAN after the Asian financial crisis. Journal of Asian Economics, 16(1), 5-28. https://doi.org/10.1016/j.asieco.2004.11.018

Coeurdacier, N., \& Guibaud, S. (2011). International portfolio diversification is better than you think. Journal of international Money and Finance, 30(2), 289-308. https://doi.org/10.1016/j. jimonfin.2010.10.003

Dajcman, S., Festic, M., \& Kavkler, A. (2012). European stock market comovement dynamics during some major financial market turmoils in the period 1997 to 2010 - a comparative DCC-GARCH and wavelet correlation analysis. Applied Economics Letters, 19(13), 1249-1256. https://doi.org/10.1080/13504851.2011.619481

Dagli, H., Sivri, U., \& Bank, S. (2011, June). International portfolio diversification opportunities between Turkey and other emerging markets. In Society of Interdisciplinary Business Research (SIBR) 2011 Conference on Interdisciplinary Business Research. https://doi. org/10.2139/ ssrn.1869347

De Gooijer, J.G., \& Sivarajasingham, S. (2008). Parametric and nonparametric Granger causality testing: Linkages between international stock markets. Physica A: Statistical Mechanics and its Applications, 387(11), 2547-2560. https://doi.org/10.1016/j.physa.2008.01.033 
DeLorenzo, Y.T. (2000, April). Shariah supervision of Islamic mutual funds. In 4th Annual Harvard Forum on Islamic Finance (Vol. 3, No. 6). Harvard University Cambridge, MA.

Dewandaru, G., Rizvi, S.A.R., Masih, R., Masih, M., \& Alhabshi, S.O. (2014). Stock market comovements: Islamic versus conventional equity indices with multi-timescales analysis. Economic Systems, 38(4), 553-571. https://doi:10.1016/j.ecosys.2014.05.003

Dunis, C.L., \& Shannon, G. (2005). Emerging markets of south-east and central Asia: Do they still offer a diversification benefit? Journal of Asset Management, 6(3), 168-190. https://doi. org/10.1057/palgrave.jam.2240174

Dwihasri, D., \& Masih, M. (2015). Should investors diversify their portfolios with stocks from major trading countries? A comparative multivariate GARCH-DCC and wavelet correlation analysis (MPRA Paper 65278). Munich, Germany: University Library of Munich.

Eagle, R.F. (1982). Autoregressive conditional heteroskedasticity with estimates of the variance of UK inflation. Econometrica, 50(4), 987-1007. https://doi.org/10.2307/1912773

El Alaoui, A.O., Dewandaru, G., Rosly, S.A., \& Masih, M. (2015). Linkages and co-movement between international stock market returns: Case of Dow Jones Islamic Dubai Financial Market index. Journal of International Financial Markets, Institutions and Money, 36(May), 53-70. https://doi.org/10.1016/j.intfin.2014.12.004

Elfakhani, S., Hassan, M.K., \& Sidani, Y. (2005, December). Comparative performance of Islamic versus secular mutual funds. In 12th Economic Research Forum Conference in Cairo, Egypt (Vol. 53, pp. 19-21).

Engle, R. (2002). Dynamic conditional correlation: A simple class of multivariate generalized autoregressive conditional heteroskedasticity models. Journal of Business \& Economic Statistics, 20(3), 339-350. https://doi.org/10.1198/073500102288618487

Engle, R. F., \& Sheppard, K. (2001). Theoretical and empirical properties of dynamic conditional correlation multivariate GARCH (NBER Working Paper, No. w8554). Cambridge, MA: National Bureau of Economic Research. https://doi.org/10.3386/w8554

Fama, E.F. (1970). Efficient capital markets: A review of theory and empirical work. The Journal of Finance, 25(2), 383-417. https://doi.org/10.2307/2325486

Fama, E.F., \& French, K.R. (1995). Size and book-to-market factors in earnings and returns. The Journal of Finance, 50(1), 131-155. https://doi.org/10.1111/j.1540-6261.1995.tb05169.x

Fantazzini, D. (2009). Value at risk for high-dimensional portfolios: A dynamic grouped-T copula approach. In The VAR implementation handbook (pp. 253-282). New York, NY: McGraw-Hill.

Gallegati, M. (2008). Wavelet analysis of stock returns and aggregate economic activity. Computational Statistics \& Data Analysis, 52(6), 3061-3074. https://doi.org/10.1016/j.csda. 2007.07.019

Gençay, R., Selçuk, F., \& Whitcher, B. (2001a). An introduction to wavelets and other filtering methods in finance and economics. San Diego, CA: Academic Press.

Gençay, R., Selçuk, F., \& Whitcher, B. (2001b). Differentiating intraday seasonalities through wavelet multi-scaling. Physica A: Statistical Mechanics and its Applications, 289(3-4), 543556. https://doi.org/10.1016/S0378-4371(00)00463-5

Grinsted, A., Moore, J.C., \& Jevrejeva, S. (2004). Application of the cross wavelet transform and wavelet coherence to geophysical time series. Nonlinear Processes in Geophysics, European Geosciences Union (EGU), 11(5/6), 561-566. hal-00302394

Grubel, H.G. (1968). Internationally diversified portfolios: Welfare gains and capital flows. The American Economic Review, 58(5), 1299-1314.

Grubel, H.G., \& Fadner, K. (1971). The interdependence of international equity markets. The Journal of Finance, 26(1), 89-94. https://doi.org/10.1111/j.1540-6261.1971.tb00591.x

Hakim, S., \& Rashidian, M. (2004), Risk and return of Islamic stock market indexes. Paper presented at the International Seminar of Nonbank Financial Institutions: Islamic Alternatives, Kuala Lumpur, Malaysia. 
Hamidi, H.N., Khalid, N., \& Karim, Z.A. (2018). Revisiting relationship between Malaysian stock market index and selected macroeconomic variables using asymmetric cointegration. Jurnal Ekonomi Malaysia, 52(1), 341-350. https://doi.org/10.17576/JEM-2018-5201-25

Hoepner, A.G.F. (2010). Portfolio diversification and environmental, social or governance criteria: Must responsible investments really be poorly diversified? SSRN Electronic Journal. https:// doi.org/10.2139/ssrn.1599334

Hourvouliades, N.L. (2009). International portfolio diversification: Evidence from European emerging markets. European Research Studies Journal, 12(4), 55-78.

Hurriyet Daily News. (2017, August 21). Turkey, Singapore aim for \$2 bln trade volume by 2018. Retrieved from http://www.hurriyetdailynews.com/turkey-singapore-aim-for-2-bln-tradevolume-by-2018-116996

Hussein, K.A. (2007). Islamic investment: Evidence from Dow Jones and FTSE indices. Islamic Economics and Finance, 387.

Ibrahim, M. (2010). Impact of the global crisis on Malaysia's financial system (BIS Paper No. 54, pp. 267-278). Basel, Switzerland: Bank for International Settlements. Retrieved from https:// www.bis.org/publ/bppdf/bispap54p.pdf

Ibrahim, M.H. (2015). Issues in Islamic banking and finance: Islamic banks, Shari'ah-compliant investment and sukuk. Pacific-Basin Finance Journal, 34(September), 185-191. https://doi. org/10.1016/j.pacfin.2015.06.002

In, F.H., \& Kim, S. (2013). An introduction to wavelet theory in finance: A wavelet multiscale approach. Singapore: World Scientific.

International Islamic Financial Market (IIFM). (2010). Sukuk report: A comprehensive study of the international sukuk market. Manama, Bahrain: Author. Retrieved from https://www.iifm.net/ wp-content/uploads/2019/10/IIFM-Sukuk-Report-1st-Edition-A-Comprehensive-study-of-theGlobal-Sukuk-Market.pdf

Jankus J.C. (1998), The Recent History of International Diversification. The Journal of Investing, 7(2), 67-76. https://doi.org/10.3905/joi.1998.408460

Jorion, P. (1989). Asset allocation with hedged and unhedged foreign stocks and bonds. Journal of Portfolio Management, 15(4), 49.

Jorion, P., \& Roisenberg, L. (1993). Synthetic international diversification. Journal of Portfolio Management, 19(2), 65-74. https://doi.org/10.3905/jpm.1993.409439

Kabir S.H., Bacha O.I., \& Masih, M. (2013). Are Islamic equities immune to global flnancial turmoil? An Investigation of the time varying correlation and volatility of Islamic equity returns. Australian Journal of Basic and Applied Sciences, 7(7), 686-701.

Leong, K.H., \& Aw, M.W. (1997). Measuring unit trust fund performance using different benchmarks. Capital Markets Review, 5(2), 27-44.

Levy, H., \& Sarnat, M. (1970). International diversification of investment portfolios. The American Economic Review, 60(4), 668-675.

Lintner, J. (1965). Security prices, risk, and maximal gains from diversification. The Journal of Finance, 20(4), 587-615. https://doi.org/10.2307/2977249

Madaleno, M., \& Pinho, C. (2010). Relationship of the multiscale variability on world indices. Revista De Economia Financiera, 20(2), 69-92.

Madaleno, M., \& Pinho, C. (2012). International stock market indices comovements: A new look. International Journal of Finance \& Economics, 17(1), 89-102. https://doi.org/10.1002/ ijfe. 448

Majid, M.S.A., \& Kassim, S.H. (2010). Potential diversification benefits across global Islamic equity markets. Journal of Economic Cooperation and Development, 31(4), 103-126.

Mansourfar, G., Mohamad, S., \& Hassan, T. (2010). A review on international portfolio diversification: The Middle East and North African region. African Journal of Business Management, 4(19), 4167-4173. 
Markellos, R.N., \& Siriopoulos, C. (1997). Diversification benefits in the smaller European stock markets. International Advances in Economic Research, 3(2), 142-153. https://doi.org/ 10.1007/BF02294935

Markowitz, H. (1952), Portfolio selection. The Journal of Finance, 7(1), 77-91.

Markowitz, H.M. (1959). Portfolio selection: Efficient diversification of investments. New York, NY: John Wiley \& Sons.

Masih, A.M., \& Masih, R. (1997). Dynamic linkages and the propagation mechanism driving major international stock markets: An analysis of the pre-and post-crash eras. The Quarterly Review of Economics and Finance, 37(4), 859-885. https://doi.org/10.1016/S1062-9769(97)90008-9

Masih, A.M., \& Masih, R. (1999). Are Asian stock market fluctuations due mainly to intra-regional contagion effects? Evidence based on Asian emerging stock markets. Pacific-Basin Finance Journal, 7(3-4), 251-282. https://doi.org/10.1016/S0927-538X(99)00013-X

Moeljadi, M. (2012). Resilience of Islamic and conventional stock markets during the 2007 global financial crisis: A comparative empirical examination. Asia-Pacific Management and Business Application, 1(1), 81-102.

Mohamad, S., \& Nassir, A.M. (1995). The performance of unit trusts in Malaysia: Some evidence. Capital Markets Review, 3(2), 51-69.

Najeeb, S.F., Bacha, O., \& Masih, M. (2015). Does heterogeneity in investment horizons affect portfolio diversification? Some insights using M-GARCH-DCC and wavelet correlation analysis. Emerging Markets Finance and Trade, 51(1), 188-208. https://doi.org/10.1080/154049 6X.2015.1011531

Narayan, P.K., \& Bannigidadmath, D. (2017). Does financial news predict stock returns? New evidence from Islamic and non-Islamic stocks. Pacific-Basin Finance Journal, 42(April), 24-45. https://doi.org/10.1016/j.pacfin.2015.12.009

$\mathrm{Ng}$, T.H. (2002). Stock market linkages in South-East Asia. Asian Economic Journal, 16(4), 353-377. https://doi.org/10.1111/1467-8381.00157

Norsworthy, J.R., Li, D., \& Gorener, R. (2000, August). Wavelet-based analysis of time series: An export from engineering to finance. In Proceedings of the 2000 IEEE Engineering Management Society. EMS-2000 (Cat. No. 00CH37139) (pp. 126-132). New York, NY: Institute of Electrical and Electronics Engineers. https://doi.org/10.1109/EMS.2000.872489

Onay, C. (2006). A co-integration analysis approach to European Union integration: The case of acceding and candidate countries. European Integration online Papers (ElOP), 10(7). Retrieved from https://www.researchgate.net/publication/5015038

Orlov, A.G. (2009). A cospectral analysis of exchange rate comovements during Asian financial crisis. Journal of International Financial Markets, Institutions and Money, 19(5), 742-758. https://doi.org/10.1016/j.intfin.2008.12.004

Paramati, S.R., Gupta, R., \& Roca, E. (2012, August). A dynamic analysis of the integration of the Australian stock market with those of its trading partners. Paper presented at the 25th Australasian Finance and Banking Conference. https://doi.org/10.2139/ssrn.2136962

Pesaran, B., \& Pesaran, M.H. (2009). Time series econometrics using Microfit 5.0: A user's manual. Oxford: Oxford University Press.

Percival, D.P. (1995). On estimation of the wavelet variance. Biometrika, 82(3), 619-631. https:// doi.org/10.1093/biomet/82.3.619

Rahim, A.M., \& Masih, M. (2016). Portfolio diversification benefits of Islamic investors with their major trading partners: Evidence from Malaysia based on MGARCH-DCC and wavelet approaches. Economic Modelling, 54(April), 425-438. https://doi.org/10.1016/j.econ$\bmod .2015 .12 .033$

Righi, M.B., \& Ceretta, P.S. (2011). Analyzing the structural behavior of volatility in the major European markets during the Greek crisis. Economics Bulletin, 31(4), 3016-3029. 
Rizvi, S.A.R., Dewandaru, G., Bacha, O.I., \& Masih, M. (2014). An analysis of stock market efficiency: Developed vs Islamic stock markets using MF-DFA. Physica A: Statistical Mechanics and its Applications, 407(August), 86-99. https://doi.org/10.1016/j.physa.2014.03.091

Ross, S.A. (1976). The arbitrage theory of capital asset pricing. Journal of Economic Theory, 13(3), 341-360. https://doi.org/10.1016/0022-0531(76)90046-6

Sadeghi, M. (2008). Financial performance of Shariah-compliant investment: Evidence from Malaysian stock market. International Research Journal of Finance and Economics, 20(8), 15-24.

Saiti, B., Bacha, O.I., \& Masih, M. (2014). The diversification benefits from Islamic investment during the financial turmoil: The case for the US-based equity investors. Borsa Istanbul Review, 14(4), 196-211. https://doi.org/10.1016/j.bir.2014.08.002

Saiti, B., Bacha, O.I., \& Masih, M. (2016). Testing the conventional and Islamic financial market contagion: Evidence from wavelet analysis. Emerging Markets Finance and Trade, 52(8), 1832-1849. https://doi.org/10.1080/1540496X.2015.1087784

Sakti, M.R.P., Masih, M., Saiti, B., \& Tareq, M.A. (2018). Unveiling the diversification benefits of Islamic equities and commodities. Managerial Finance, 44(6), 830-850. https://doi. org/10.1108/MF-08-2017-0278

Sharpe, W.F. (1964). Capital asset prices: A theory of market equilibrium under conditions of risk. The Journal of Finance, 19(3), 425-442. https://doi.org/10.1111/j.1540-6261.1964.tb02865.x

Smimou, K. (2011). Transition to the Euro and its impact on country portfolio diversification. Research in International Business and Finance, 25(1), 88-103. https://doi.org/10.1016/j. ribaf.2010.08.001

Solnik, B.H. (1974). Why not diversify internationally rather than domestically? Financial Analysts Journal, 30(4), 48-54. https://doi.org/10.2469/faj.v30.n4.48

Solnik, B., \& Noetzlin, B. (1982). Optimal international asset allocation. The Journal of Portfolio Management, 9(1), 11-21. https://doi.org/10.3905/jpm.1982.408895

Thomson Reuters. (2016). Thomson Reuters global Islamic asset management outlook 2015. Retrieved from http://thomsonreuters.com/en/press-releases/2015/05/thomson-reutersreleases-global islamic-asset-management-outlook-report.html

Tiwari, A.K. (2013). Oil prices and the macroeconomy reconsideration for Germany: Using continuous wavelet. Economic Modelling, 30(January), 636-642. https://doi.org/10.1016/j. econmod.2012.11.003

Umirah, F., \& Masih, M. (2017). Should the Malaysian Islamic stock market investors invest in regional and international equity market to gain portfolio diversification benefits? (MPRA paper 82117). Munich, Germany: University Library of Munich

Whitcher, B., Guttorp, P., \& Percival, D.B. (2000). Wavelet analysis of covariance with application to atmospheric time series. Journal of Geophysical Research: Atmospheres, 105(D11), 1494114962. https://doi.org/10.1029/2000JD900110

Worthington, A.C., Katsuura, M., \& Higgs, H. (2003). Price linkages in Asian equity markets: Evidence bordering the Asian economic, currency and financial crises. Asia-Pacific Financial Markets, 10(1), 29-44. https://doi.org/10.1023/B:FEJM.0000039873.53973.3c

Xiao, L., \& Dhesi, G. (2010). Volatility spillover and time-varying conditional correlation between the European and US stock markets. Global Economy and Finance Journal, 3(2), 148-164. 